\title{
ANALISIS PARAMETER OSEANOGRAFI DAN LINGKUNGAN EKOWISATA PANTAI DI PANTAI PANJANG KOTA BENGKULU
}

\author{
Apriliansyah, Dewi Purnama, Yar Johan, Person Pesona Renta \\ Program Studi IImu Kelautan Universitas Bengkulu \\ E-mail: liansyah.a.ns@gmail.com
}

Received Agustus 2018, Accepted September 2018

\begin{abstract}
ABSTRAK
Ekowisata pantai adalah kegiatan ekowisata yang dilakukan di daerah pantai pada umumnya memanfaatkan sumberdaya pantai dan permukaan air. Pantai Panjang Kota Bengkulu merupakan pantai yang terdapat di bagian barat Pulau Sumatera dan berbatasan langsung dengan Samudera Hindia. Pantai Panjang yang membentang sepanjang $7 \mathrm{~km}$ dengan luas 84,09 ha. Penelitian ini bertujuan untuk menganalisis parameter oseanografi dan lingkungan ekowisata pantai di Pantai Panjang Kota Bengkulu. Metode yang dilakukan dalam penelitian ini adalah metode survei. Hasil penelitian ini diperoleh sebaran parameter oseanografi dan lingkungan dalam kondisi mendukung untuk kegiatan ekowisata pantai. Parameter-parameter tersebut yaitu tipe pantai, lebar pantai $(m)$, material dasar perairan, kecepatan arus, kecerahan perairan $(\%)$, penutupan lahan pantai, biota berbahaya, ketersediaan air tawar $(\mathrm{m})$ dan kedalaman perairan $(\mathrm{cm})$.
\end{abstract}

Kata Kunci : Parameter Oseanografi, Ekowisata Pantai, Pantai Panjang

\begin{abstract}
Coastal ecotourism is an ecotourism activity carried out in coastal areas generally utilizing coastal resources and surface water. Panjang Beach in Bengkulu is located in the western side of Sumatra Island and directly adjacent to the Indian Ocean. This beach has $7 \mathrm{~km}$ of coastline and 84,09 ha of beach area. This research aims to analyze oceanographic parameters and coastal ecotourism environment in Pantai Panjang, Bengkulu City. The method used in this research was survey method. The results of this research obtained the distribution of oceanographic and environmental parameters in supporting conditions for coastal ecotourism activities. These parameters are beach type, beach width $(m)$, water base material, current velocity, water brightness (\%), coastal land cover, dangerous biota, fresh water availability $(\mathrm{m})$ and water depth $(\mathrm{cm})$.
\end{abstract}

Keywords : Oceanographic Parameters, Coastal Ecotourism, Panjang Beach 


\section{PENDAHULUAN}

Sumberdaya wilayah pesisir dan laut terdiri atas 1). Sumberdaya dapat pulih (renewable resources) atau sering juga disebut sumberdaya alam hayati, diantaranya adalah terumbu karang (coral reef), rumput laut (seaweed), padang lamun (seagrass) dan mangrove, 2). Sumberdaya tidak dapat pulih (nonrenewable resources) atau disebut sumberdaya alam non-hayati, meliputi minyak bumi dan gas, mineral, bahan tambang/galian seperti bijih besi, pasir, timah, bauksit, serta bahan tambang lainnya dan 3) Jasa-jasa lingkungan pesisir dan laut (environmental services), salah satunya adalah ekowisata. Menurut Bjork (2000); Yulianda (2007); Yulianda dkk., (2010); dan Fadrika dkk., (2015) ekowisata adalah konsep pengembangan pariwisata berkelanjutan dengan tujuan untuk mendukung pada pelestarian lingkungan.

Ekowisata pantai adalah kegiatan ekowisata yang dilakukan di daerah pantai pada umumnya memanfaatkan sumberdaya pantai dan permukaan air (Yulianda dkk., 2010). Nilai visual lanskap yang estetik atau lebih dikenal dengan Scenic Beauty Estimation (SBE) adalah salah satu faktor pendorong suatu kawasan pada kegiatan ekowisata pantai untuk melepaskan kepenatan dan rutinitas pekerjaan, selain itu keberadaan visual dapat menjadi parameter keadaan kualitas suatu tapak atau bentang alam (Budiyono dan Soelistyari, 2016).

Parameter yang digunakan antara lain kedalaman perairan, tipe pantai, material dasar, kecepatan arus, penutupan lahan pantai, jarak ketersediaan air tawar (Yulianda, 2007; Senoaji dan Hidayat, 2009; Yulianda $d k k$., 2010). Lebar pantai, kemiringan, kecerahan perairan dan biota berbahaya (Yulianda, 2007; Yulianda dkk., 2010). Kedalaman berpengaruh pada aspek keselamatan pada saat ekowisata pantai, kedalaman perairan yang dangkal cukup baik untuk untuk kegiatan ekowisata pantai), sedangkan kecepatan arus erat kaitannya dengan kenyamanan wisatawan yang datang ke objek ekowisata tersebut jika arus dalam keadaan kencang sebaiknya pengunjung tidak melakukan aktivitas ekowisata karena akan berbahaya untuk keselamatan pengunjung yang datang, jika kecepatan arus relatif tenang akan memberikan kesan kenyamanan bagi wisatawan yang ingin melakukan aktivitas ekowisata (Wabang dkk., 2017). Menurut Yulianda (2007) bahwa terkait tipe pantai, akan sangat baik jika pantai yang berpasir atau dengan kata lain didominasi oleh substrat pasir, dibandingkan dengan pantai yang berbatu atau pantai yang didominasi oleh substrat karang, karena dapat mengganggu kenyamanan wisatawan. Pengamatan biota berbahaya perlu dilakukan untuk mengetahui ada atau tidaknya biota berbahaya yang akan mengganggu pengunjung. Adapun biota berbahaya bagi pengunjung ekowisata diantaranya bulu babi, ubur-ubur, dan ular laut (Lelloltery $d k k$., 2016; Wabang $d k k$., 2017).

Pantai Panjang Kota Bengkulu merupakan pantai yang terdapat di bagian barat Pulau Sumatera dan berbatasan langsung dengan 
Samudera Hindia, Pantai Panjang yang membentang sepanjang $7 \mathrm{~km}$ dengan luas 84,09 ha tergolong ke dalam kategori jenis pantai lurus di daratan yang landai (Nugraha $d k k$. 2013). Tujuan dari penelitian ini adalah menganalisis parameter oseanografi dan lingkungan ekowisata pantai di Pantai Panjang Kota Bengkulu.

\section{MATERI DAN METODE}

\section{Waktu dan Tempat Penelitian}

Penelitian ini dilaksanakan pada bulan April sampai dengan Juli 2018 di Pantai Panjang Kota Bengkulu Provinsi Bengkulu (Gambar 1) dan titik koordinat lokasi penelitian di Pantai Panjang Kota Bengkulu pada Tabel 1.
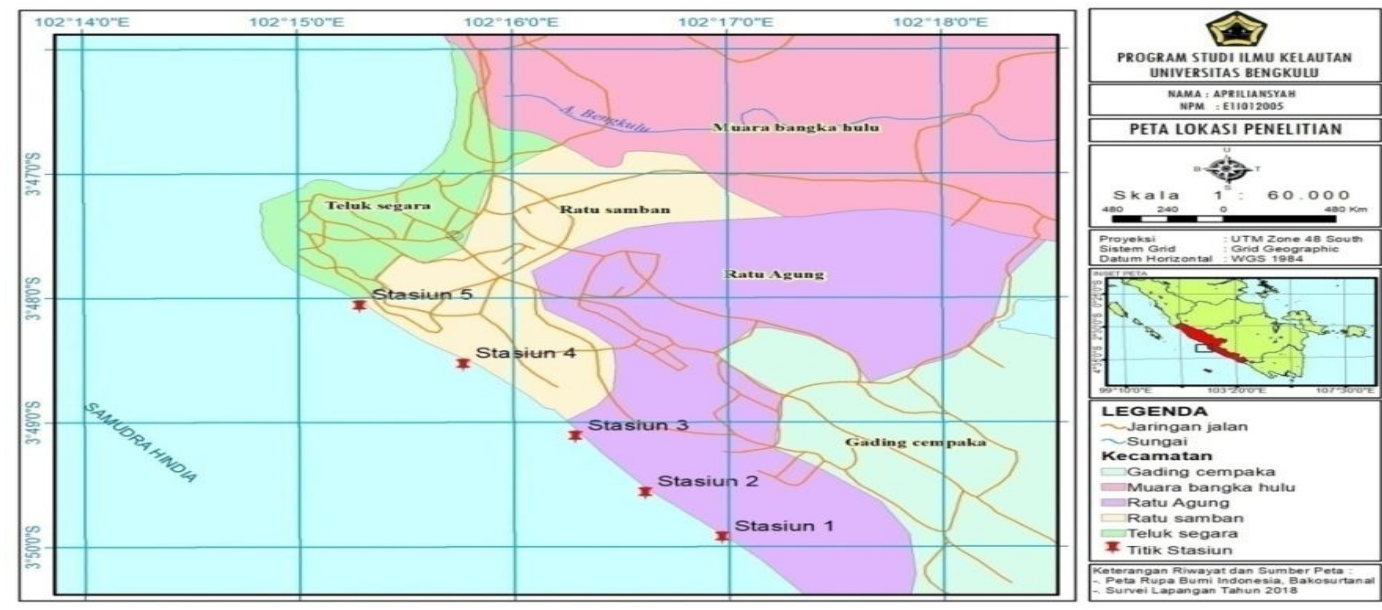

Gambar 1. Lokasi penelitian

Tabel 1. Titik koordinat lokasi penelitian

\begin{tabular}{ccc}
\hline \multirow{2}{*}{ Lokasi Penelitian } & \multicolumn{2}{c}{ Titik Koordinat } \\
\cline { 2 - 3 } & Latitude $^{\prime}$ & Longitude \\
\hline Stasiun 1 & $03^{0} 49.934^{\prime}$ & $102^{0} 16.978^{\prime}$ \\
Stasiun 2 & $03^{0} 49.575^{\prime}$ & $102^{0} 16.622^{\prime}$ \\
Stasiun 3 & $03^{0} 49.123^{\prime}$ & $102^{0} 16.295^{\prime}$ \\
Stasiun 4 & $03^{0} 48.541^{\prime}$ & $102^{0} 15.775^{\prime}$ \\
Stasiun 5 & $03^{0} 48.071^{\prime}$ & $102^{0} 15.292^{\prime}$ \\
\hline
\end{tabular}

\section{Metode Pengambilan Data}

\section{Data Parameter Oseanografi}

Metode pengukuran parameter oseanografi dilakukan secara sengaja (purposive sampling) berdasarkan juga adanya aktivitas 
ekowisata pantai dengan stasiun pengamatan adalah pada Stasiun 1, Stasiun 2, Stasiun 3, Stasiun 4 dan Stasiun 5 (lihat Gambar 1) di lakukan masing-masing pengamatan 3 kali ulangan pada setiap lokasi pengamatan. Data parameter oseanografi yang diperlukan dalam penelitian ini dapat dilihat pada Tabel 2.

Tabel 2. Data parameter oseanografi

\begin{tabular}{llll}
\hline No & Paremeter & Satuan & Alat dan Bahan \\
\hline 1 & Kedalaman & $\mathrm{cm}$ & Tali penduga/Papan skala \\
2 & Kecepatan arus & $\mathrm{m} / \mathrm{s}$ & Parasut arus/Stop watch \\
3 & Kecerahan perairan & $\mathrm{m}$ & Secchi disk \\
4 & Lebar pantai & $\mathrm{m}$ & Roll meter \\
5 & Suhu & ${ }^{0} \mathrm{C}$ & Thermometer \\
6 & Salinitas & $0 \% 00$ & Refraktometer \\
7 & $\mathrm{pH}$ & - & pH meter \\
\hline
\end{tabular}

\section{Data Parameter Lingkungan}

Metode pengukuran parameter lingkungan dilakukan secara sengaja (purposive sampling) berdasarkan juga adanya aktivitas ekowisata pantai dengan stasiun pengamatan adalah pada Stasiun 1, Stasiun 2, Stasiun 3, Stasiun 4 dan Stasiun 5 (lihat Gambar 1) di lakukan masing-masing pengamatan 3 kali ulangan pada setiap lokasi pengamatan. Data parameter lingkungan yang diperlukan dalam penelitian ini dapat dilihat pada Tabel 3.

Tabel 3. Data parameter lingkungan

\begin{tabular}{lll}
\hline No & Paremeter & Alat dan Bahan \\
\hline 1 & Tipe pantai & Identifikasi secara visual \\
2 & Material dasar perairan & Identifikasi secara visual \\
3 & Penutupan lahan pantai & Identifikasi secara visual \\
4 & Jarak ketersediaan air tawar & Roll meter \\
5 & Biota berbahaya & Identifikasi secara visual \\
\hline
\end{tabular}

\section{Analisis Parameter Oseanografi dan Lingkungan}

Analisis parameter oseanografi dan lingkungan di lakukan secara deskriptif dalam bentuk gambar, tabel dan grafik yang menjadi parameter dalam menentukan kesesuaian ekowisata pantai kategori rekreasi dan kesesuaian ekowisata pantai kategori olahraga dan berjemur. 


\section{HASIL DAN PEMBAHASAN}

\section{Analisis Indikator Kesesuaian Ekowisata Pantai}

\section{Analisis Parameter Oseanografi}

Hasil penelitian diperoleh nilai rata-rata parameter oseanografi pada lokasi penelitian dapat dilihat pada Tabel 4.

Tabel 4. Nilai rata-rata paramater oseanografi

\begin{tabular}{llccccc}
\hline & & \multicolumn{5}{c}{ Lokasi Penelitian } \\
\cline { 3 - 7 } No & Parameter & Stasiun & Stasiun & Stasiun & Stasiun & Stasiun \\
& & 1 & 2 & 3 & 4 & 5 \\
\hline 1 & Kedalaman (cm) & 96,67 & 106,00 & 95,67 & 87,33 & 61,33 \\
2 & Kecerahan (\%) & 39,83 & 31,60 & 47,56 & 61,26 & 47,28 \\
3 & Salinitas (\%o) & 32,33 & 32,00 & 33,00 & 33,33 & 34,33 \\
4 & Lebar Pantai (m) & 33,67 & 46,67 & 73,47 & 62,33 & 73,17 \\
& Kecepatan Arus & & & & & \\
5 & (m/s) & 0,33 & 0,66 & 0,70 & 0,70 & 0,59 \\
6 & Suhu ( $\left.{ }^{\circ} \mathrm{C}\right)$ & 29,17 & 30,17 & 31,20 & 30,87 & 31,10 \\
7 & pH & 7,83 & 7,77 & 7,90 & 7,90 & 7,90 \\
\hline
\end{tabular}

\section{Kedalaman}

Hasil penelitian didapat (Gambar 2) kedalaman perairan tepi Pantai Panjang yang ada di Kota Bengkulu, Stasiun 2 merupakan nilai untuk tepi pantai yang paling dalam dengan nilai $106,00 \mathrm{~cm}$ sedangkan untuk kedalaman yang paling dangkal terdapat pada stasiun 5 dengan nilai $61,33 \mathrm{~cm}$. Kedalaman perairan yang terukur berkisar antara 61,33-106,00 $\mathrm{cm}$, ini menunjukkan bahwa kedalaman perairan Pantai Panjang masuk ke dalam kategori sangat sesuai untuk dijadikan ekowisata pantai.

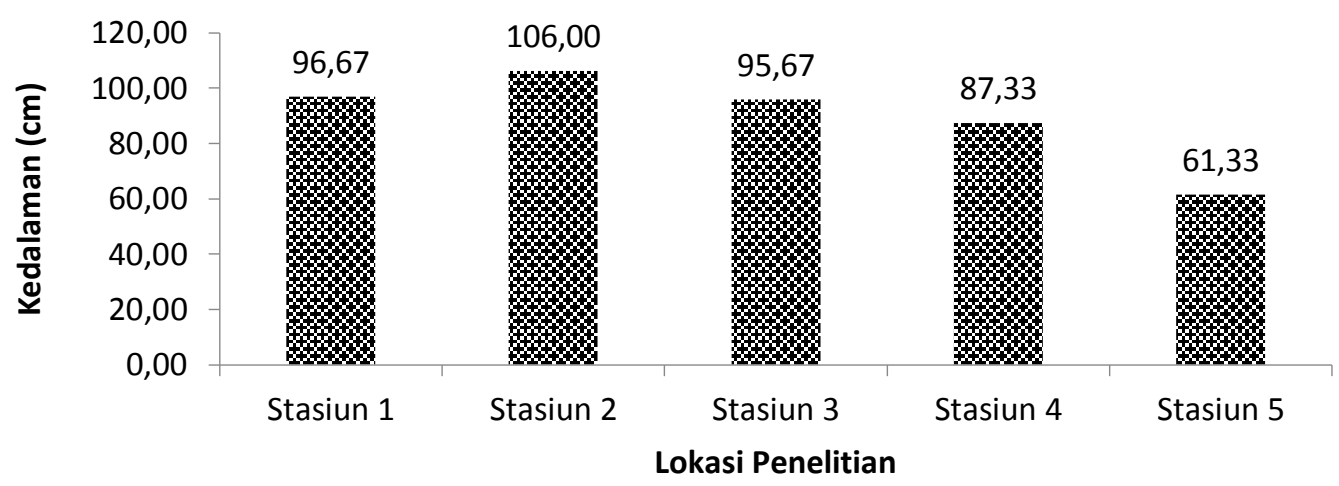

Gambar 2. Diagram sebaran kedalaman rata-rata di Perairan Pantai Panjang 
Kedalaman perairan menjadi faktor penting dalam penentuan suatu kawasan untuk dijadikan sebuah kawasan ekowisata pantai karena berhubungan dengan kegiatan mandi dan berenang oleh wisatawan yang datang ke Pantai Panjang. Hal ini juga berhubungan dengan keselamatan wisatawan. Secara fisik kedalaman perairan yang dangkal cukup baik untuk dijadikan sebagai tempat aktivitas rekreasi, mandi dan berenang. Menurut Yusthisar dkk. (2012), bahwa kedalaman perairan yang tidak terlalu dalam dapat dilakukan kegiatan ekowisata berenang. Kegiatan berenang tidak dapat dilakukan atau akan menjadi resiko yang tinggi jika kedalaman lebih dari $5 \mathrm{~m}$.

Kedalaman perairan Pantai Panjang relatif dangkal dan baik untuk dijadikan untuk objek ekowisata pantai kategori rekreasi terutama mandi dan berenang kedalaman yang baik yaitu berkisar 0-1,5 m. Sehingga dapat disimpulkan bahwa berdasarkan pengukuran kedalaman perairan, Pantai Panjang sangat sesuai untuk ekowisata pantai dalam kategori rekreasi (Yulianda, 2007).

\section{Kecerahan}

Hasil pengukuran kecerahan air laut di Pantai Panjang yang memiliki kecerahan paling tinggi dengan nilai $61,26 \%$ dan yang paling rendah dengan nilai $31,60 \%$, sebagaimana yang dikemukakan oleh Yulianda (2007), bahwa suatu parameter kecerahan perairan untuk kategori ekowisata pantai seharusnya memiliki kecerahan perairan yaitu lebih dari $10 \mathrm{~m}$.

Kecerahan perairan dalam kaitannya dengan kegiatan ekowisata pantai sangat berperan dalam hal kenyamanan para wisatawan pada saat mandi dan berenang. Pengukuran kecerahan di lokasi penelitian dilakukan dengan cara menggunakan secchi disk yang diikat dengan tali kemudian diturunkan perlahan-lahan ke dalam perairan pada lokasi penelitian sampai pada batas visual secchi disk tersebut tidak dapat terlihat lalu mengukur panjang tali dan mencatat posisi pengambilan data. Kecerahan perairan dapat dilihat pada Gambar 3.

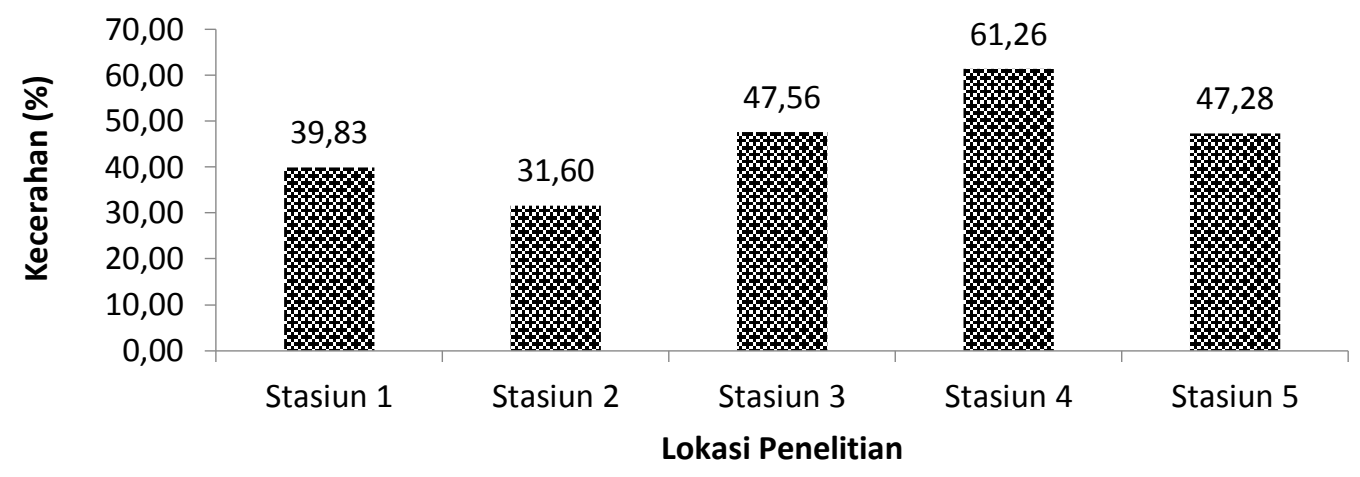

Gambar 3. Diagram sebaran kecerahan rata-rata di Perairan Pantai Panjang 
Kecerahan air merupakan ukuran kejernihan suatu perairan, semakin tinggi suatu kecerahan perairan semakin dalam cahaya menembus ke dalam air. Kecerahan air menentukan ketebalan lapisan produktif. Berkurangnya kecerahan air akan mengurangi kemampuan fotosintesis tumbuhan air, selain itu dapat pula mempengaruhi kegiatan fisiologi biota air, dalam hal ini bahan-bahan ke dalam suatu perairan terutama yang berupa suspensi dapat mengurangi kecerahan air (Effendi, 2003).

Berdasarkan baku mutu perairan untuk ekowisata bahari yang ditetapkan oleh Kepmen LH (2004) kecerahan yang baik merupakan yang nilai kecerahan nya lebih dari $6 \mathrm{~m}$. Tingkat kecerahan perairan Pantai Panjang sangat dipengaruhi oleh keadaan cuaca, waktu pengukuran, padatan tersuspensi dan kekeruhan serta ketelitian orang yang melakukan pengukuran (Effendi, 2003).

\section{Salinitas}

Pengukuran parameter salinitas (Gambar 4) atau tingkat keasinan atau kadar garam terlarut dalam air laut yang ada di Pantai Panjang Kota Bengkulu berkaitan dengan kualitas suatu perairan.

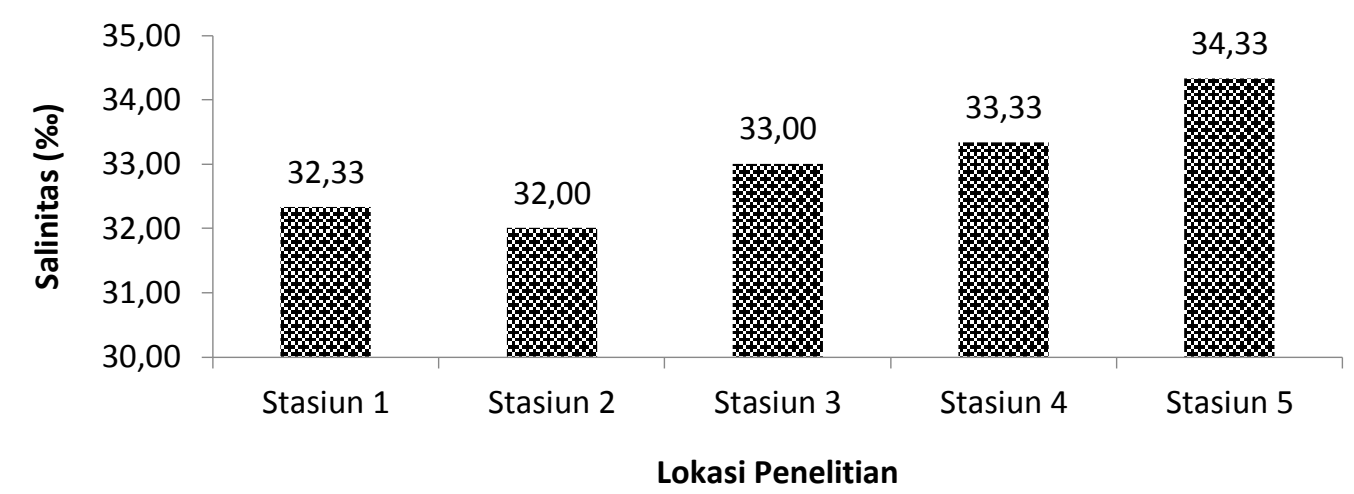

Gambar 4. Diagram sebaran salinitas rata-rata di Perairan Pantai Panjang

Hasil penelitian pada Gambar 4 menunjukkan bahwa tingkat salinitas tertinggi ada pada Stasiun 5 dengan nilai salinitas 34,33\%o, sedangkan nilai yang paling rendah ada pada Stasiun 2 dengan nilai $32,00 \%$ o. Salinitas perairan biasanya dipengaruhi oleh evaporasi (penguapan) air laut, curah hujan, dan percampuran air. Menurut Bengen (2002) nilai salinitas yang baik berkisar antara 30,00\% sampai dengan 36,00\%o, maka salinitas di Perairan Pantai Panjang termasuk dalam kisaran salinitas yang baik untuk kegiatan ekowisata pantai.

\section{Lebar Pantai}

Hasil pengukuran lebar pantai pada Pantai Panjang (Gambar 5). Pada Stasiun 3 dan Stasiun 5 memiliki ukuran lebar pantai terpanjang 
yang mencapai 73,47 m dan 73,17 m sedangkan untuk lebar pantai yang paling kecil ada pada Stasiun 1 yaitu dengan lebar 33,67 $\mathrm{m}$.

Pengukuran lebar pantai hubungannya dengan kegiatan ekowisata dimaksudkan untuk mengetahui seberapa luas wilayah pantai yang dapat digunakan untuk berbagai kegiatan ekowisata pantai dan diukur dari akhir vegetasi terakhir di daratan hingga batas surut terendah.

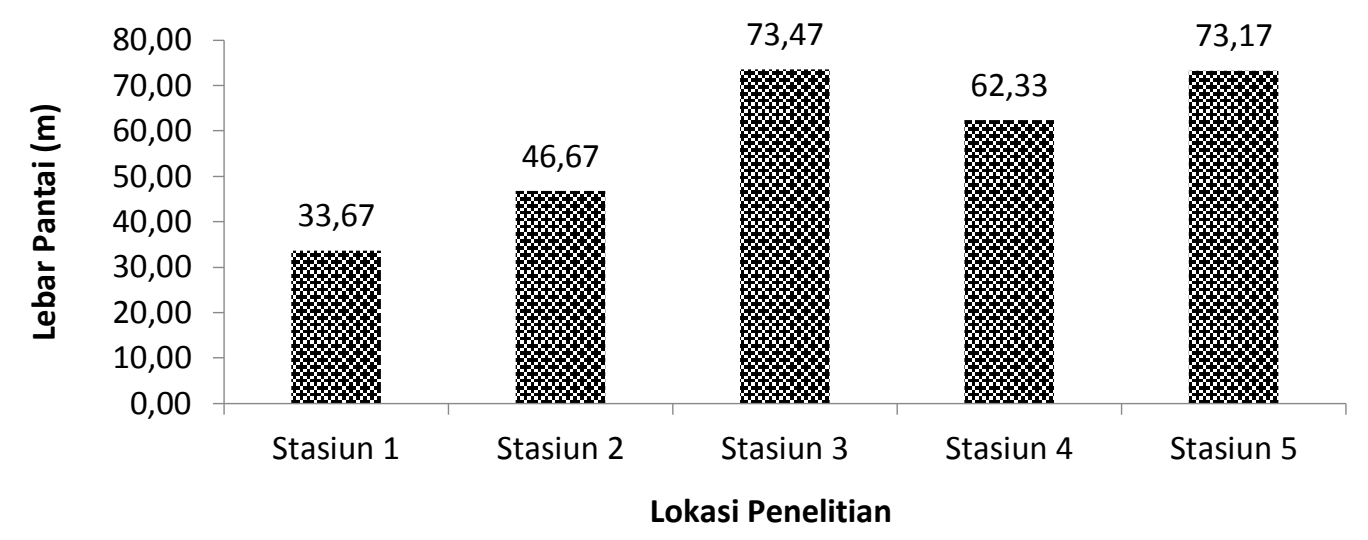

Gambar 5. Diagram sebaran lebar pantai rata-rata di Pantai Panjang

Berdasarkan hasil pengukuran lebar pantai (Gambar 5) menunjukkan bahwa lebar pantai di Pantai Panjang berkisar 33,67-73,47 m. Lebar pantai ini sangat memungkinkan wisatawan dapat melakukan banyak aktifitas ekowisata seperti bermain pasir, olahraga pantai (sepakbola dan motor pantai), berjemur, berfoto dan bermain di tepi pantai. Lebar Pantai Panjang ini sudah >15 m dan berdasarakan pendapat Yulianda (2007) pantai ini sangat sesuai untuk kegiata $n$ ekowisata pantai. Lebar Pantai Panjang juga didukung oleh kelandaian pantai sehingga mempengaruhi keamanan dan kenyamanan pengunjung dalam melakukan aktivitasnya di tepi pantai. Pantai menurut bentuknya terdiri dari pantai datar, landai, curam dan terjal dan untuk kegiatan ekowisata yang baik merupakan pantai yang datar dan landai (Yulianda, 2007).

\section{Kecepatan Arus}

Kecepatan arus air laut yang ada di Pantai Panjang jika dilihat dari Gambar 6 menunjukan bahwa kecepatan arus di Pantai Panjang dapat dikatakan kecepatan arus yang kuat. Kecepatan arus rata-rata tertinggi dengan nilai $0,70 \mathrm{~m} / \mathrm{s}$ di Stasiun 3 dan Stasiun 4 sedangkan untuk kecepatan arus yang paling rendah ada pada Stasiun 1 dengan nilai 0,33 $\mathrm{m} / \mathrm{s}$.

Beberapa jenis kecepatan arus yang umum dikenal adalah arus pasang surut, arus akibat gelombang (arus sejajar pantai), arus akibat tiupan angin, dan arus yang disebabkan oleh perbedaan densitas air laut (Sudarto, 1993). 


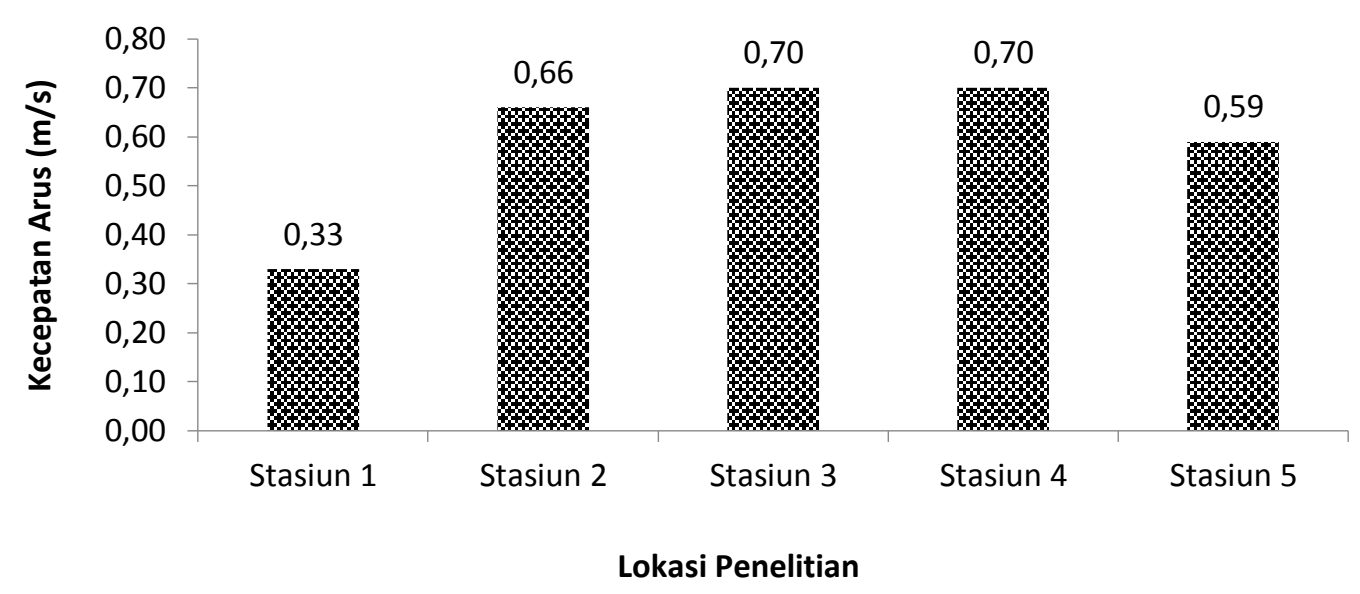

Gambar 6. Diagram sebaran kecepatan arus rata-rata di Perairan Pantai Panjang

Kecepatan arus erat kaitannya dengan keamanan ekowisata berenang. Arus yang lemah sangat baik untuk kegiatan renang, sedangkan arus yang kuat berbahaya karena dapat menyeret wisatawan yang sedang mandi atau berenang di pantai (Nybakken, 1992).

Kecepatan arus juga berhubungan dengan keamanan dan kenyamanan kegiatan ekowisata. Kecepatan arus yang terlalu tinggi akan membahayakan pengunjung, mengingat tidak adanya pembatasan pasti kawasan yang diperbolehkan untuk berenang di Pantai Panjang Kota Bengkulu. Hasil pengukuran kecepatan arus pada Gambar 6 menurut Yulianda (2007) termasuk dalam kategori tidak sesuai untuk dijadikan ekowisata pantai karena memiliki kecepatan arus mulai dari 0,33-0,70 m/s.

\section{Suhu}

Suhu perairan pengamatan pada Gambar 7 berkisar pada $29,17^{\circ} \mathrm{C}$ sampai dengan $31,20^{\circ} \mathrm{C}$, dimana suhu tertinggi pada Stasiun 3 dan suhu terendah pada Stasiun 1. Parameter suhu sangat penting dimana mempengaruhi keberadaan ekosistem di perairan dan wisatawan yang melakukan kontak dengan air. Bengen (2002) mengemukakan bahwa suhu perairan yang optimal untuk wilayah perairan pantai berada pada kisaran $23{ }^{\circ} \mathrm{C}$ sampai dengan $35{ }^{\circ} \mathrm{C}$ dengan batas toleransi berkisar antara $36{ }^{\circ} \mathrm{C}$ sampai dengan $40{ }^{\circ} \mathrm{C}$, maka suhu perairan Pantai Panjang Kota Bengkulu termasuk dalam kategori yang baik.

Berdasarkan Kepmen LH (2004) temperatur air yang baik untuk ekowisata bahari, yaitu temperatur alami $27{ }^{\circ} \mathrm{C}$ dengan fluktuasi $<2{ }^{\circ} \mathrm{C}$ dari suhu alami. 


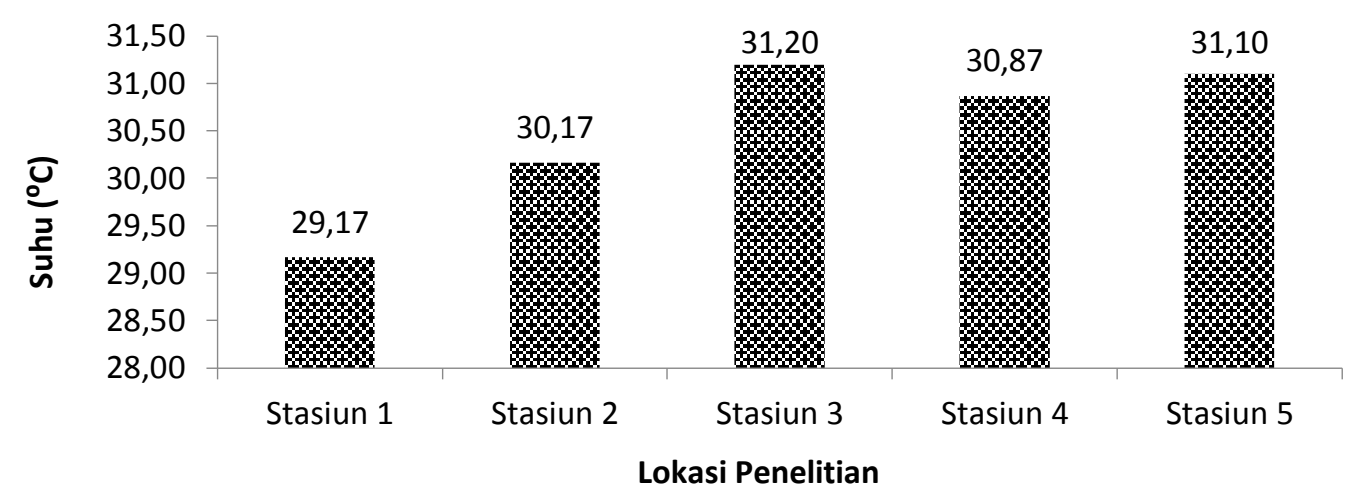

Gambar 7. Diagram sebaran suhu rata-rata di Perairan Pantai Panjang

Suhu air laut dipengaruhi oleh sinar matahari. Suhu di laut berkaitan dengan oksigen terlarut. Semakin tinggi suhu maka akan terjadi penguapan dan kandungan oksigen akan semakin rendah. Apabila kandungan oksigen terlarut rendah maka kualitas perairan tersebut dalam kondisi yang rentan terhadap dampak yang tidak baik untuk organisme dan kawasan ekowisata tersebut.

Menurut Isnaini (2011) peningkatan suhu juga disebabkan oleh proses pembusukan yang dilakukan organisme pembusuk. Peningkatan suhu berpengaruh pada peningkatan laju metabolisme sehingga oksigen yang digunakan semakin banyak. Adanya perubahan suhu pada badan air akan berpengaruh pada peningkatan sifat racun zat kimia yang ada dan ini merupakan suatu polutan pada badan air.

\section{pH}

Pengukuran parameter $\mathrm{pH}$ pada Gambar 8 dapat dilihat tingkat $\mathrm{pH}$ perairan Pantai Panjang yang tertinggi dengan nilai 7,90 terdapat pada Stasiun 3, 4 dan 5 sedangkan untuk nilai $\mathrm{pH}$ terendah dengan nilai 7,77 pada Stasiun 2. Kepmen LH (2004) menyatakan kegiatan ekowisata bahari, standar $\mathrm{pH}$ air laut berkisar antara 7 hingga 8,5. Berdasarkan hal tersebut maka nilai $\mathrm{pH}$ di perairan Pantai Panjang layak untuk dilakukan aktivitas ekowisata pantai.

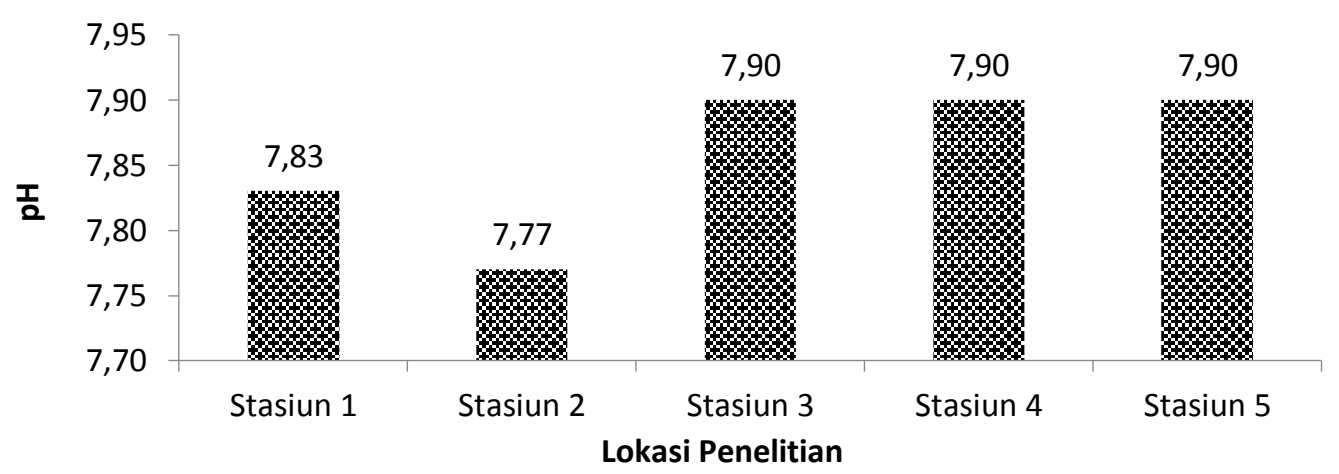

Gambar 8. Diagram sebaran $\mathrm{pH}$ rata-rata di Perairan Pantai Panjang 
Perubahan nilai derajat keasaman $(\mathrm{pH})$ dan konsentrasi oksigen yang berperan sebagai indikator kualitas perairan dapat terjadi sebagai akibat berlimpahnya senyawa-senyawa kimia baik yang bersifat polutan maupun bukan polutan. Limbah yang mengalir ke dalam perairan laut pada umumnya kaya akan bahan organik, berasal dari bermacam sumber seperti limbah rumah tangga, pengolahan makanan dan bermacam industri kimia lainnya. Bahan organik dalam limbah tersebut terdapat dalam bentuk senyawa kimia seperti karbohidrat, protein, lemak, humus, surfaktan dan berbagai zat kimia lainnya (Susana, 2009).

Perubahan kualitas air dapat menyebabkan air laut yang bersifat basa berubah menjadi bersifat asam. Rendahnya nilai $\mathrm{pH}$ mengindikasikan menurunnya kualitas perairan yang pada akhirnya berdampak terhadap kegiatan di kawasan ekowisata. Menurut Isnaini (2011) secara ideal nilai $\mathrm{pH}$ yang digunakan untuk mandi dan berenang harus sama dengan nilai $\mathrm{pH}$ yang terkandung dalam cairan mata manusia yaitu sekitar 7,4 . Tetapi karena cairan itu dapat mempunyai kemampuan buffer maka rentang nilai $\mathrm{pH}$ antara 6,5-8,3 dapat ditoleransi dalam keadaan normal.

\section{Analisis Parameter Lingkungan}

Hasil penelitian diperoleh nilai rata-rata parameter lingkungan pada lokasi penelitian dapat dilihat pada Tabel 5.

Tabel 5. Nilai rata-rata paramater lingkungan

\begin{tabular}{|c|c|c|c|c|c|c|}
\hline \multirow[b]{2}{*}{ No } & \multirow[b]{2}{*}{ Parameter } & \multicolumn{5}{|c|}{ Lokasi Penelitian } \\
\hline & & $\begin{array}{c}\text { Stasiun } \\
1\end{array}$ & $\begin{array}{l}\text { Stasiun } \\
2\end{array}$ & $\begin{array}{c}\text { Stasiun } \\
3\end{array}$ & $\begin{array}{c}\text { Stasiun } \\
4\end{array}$ & $\begin{array}{l}\text { Stasiun } \\
5\end{array}$ \\
\hline 1 & Tipe Pantai & $\begin{array}{l}\text { Pantai } \\
\text { berpasir }\end{array}$ & $\begin{array}{l}\text { Pantai } \\
\text { berpasir }\end{array}$ & $\begin{array}{l}\text { Pantai } \\
\text { berpasir }\end{array}$ & $\begin{array}{l}\text { Pantai } \\
\text { berpasir }\end{array}$ & $\begin{array}{l}\text { Pantai } \\
\text { berpasir } \\
\text {, karang }\end{array}$ \\
\hline 2 & $\begin{array}{l}\text { Material Dasar } \\
\text { Perairan }\end{array}$ & Pasir & Pasir & Pasir & Pasir & $\begin{array}{l}\text { Pasir, } \\
\text { karang }\end{array}$ \\
\hline 3 & $\begin{array}{l}\text { Biota } \\
\text { Berbahaya }\end{array}$ & $\begin{array}{l}\text { Tidak } \\
\text { ada }\end{array}$ & $\begin{array}{l}\text { Tidak } \\
\text { ada }\end{array}$ & $\begin{array}{l}\text { Tidak } \\
\text { ada }\end{array}$ & $\begin{array}{l}\text { Tidak } \\
\text { ada }\end{array}$ & $\begin{array}{l}\text { Tidak } \\
\text { ada }\end{array}$ \\
\hline 4 & $\begin{array}{l}\text { Penutupan } \\
\text { Lahan Pantai }\end{array}$ & $\begin{array}{l}\text { Cemara } \\
\text {, saung }\end{array}$ & $\begin{array}{l}\text { Cemara } \\
\text { belukar }\end{array}$ & $\begin{array}{l}\text { Cemara } \\
\text { belukar }\end{array}$ & $\begin{array}{l}\text { Cemara } \\
\text {, saung }\end{array}$ & $\begin{array}{l}\text { Cemara, } \\
\text { belukar }\end{array}$ \\
\hline 5 & $\begin{array}{l}\text { Jarak } \\
\text { Ketersediaan } \\
\text { Air Tawar (m) }\end{array}$ & 50 & 100 & 100 & 25 & 200 \\
\hline
\end{tabular}



berikut:

Hasil analisis parameter-parameter lingkungan yang diukur sebagai

\section{Tipe Pantai}

Tipe pantai dapat dilihat dari jenis substrat atau sedimen yang didukung dengan pengamatan secara visual, dalam pedoman perencanaan bangunan pengaman pantai Indonesia, di Indonesia sendiri diidentifikasikan ada tiga jenis utama tipe pantai yang dapat dibedakan berdasarkan substrat atau sedimen, yaitu pantai berpasir, pantai berlumpur dan pantai berkarang.

Berdasarkan hasil pengamatan di lokasi penelitian menunjukkan bahwa tipe pantai berpasir putih (Gambar 9) dan tipe pasir sedikit berkarang pada Stasiun 5, sehingga hal ini merupakan salah satu keunikan yang dimiliki Pantai Panjang karena memberikan kesan tersendiri bagi pengunjung yang datang ke pantai terutama bagi pengunjung yang ingin melakukan rekreasi pantai. Hal ini sesuai dengan pendapat Yulianda (2007) bahwa untuk ekowisata pantai akan sangat baik jika suatu pantai merupakan pantai yang berpasir atau dengan kata lain didominasi oleh substrat pasir, dibandingkan dengan pantai yang berbatu atau pantai yang didominasi substrat karang dapat mengganggu kenyamanan wisatawan dalam aktivitas khususnya mandi dan berenang.

Hasil pengamatan secara visual terhadap warna pasir di Pantai Panjang Kota Bengkulu adalah warna putih dengan sedimen yang halus hingga agak kasar (sedang). Jenis dan warna pasir pada suatu objek ekowisata memberikan nilai tersendiri bagi estetika pantai, pantai yang memiliki pasir warna putih sering diminati oleh wisatawan (Pangesti, 2007 dalam Hazeri, 2014).
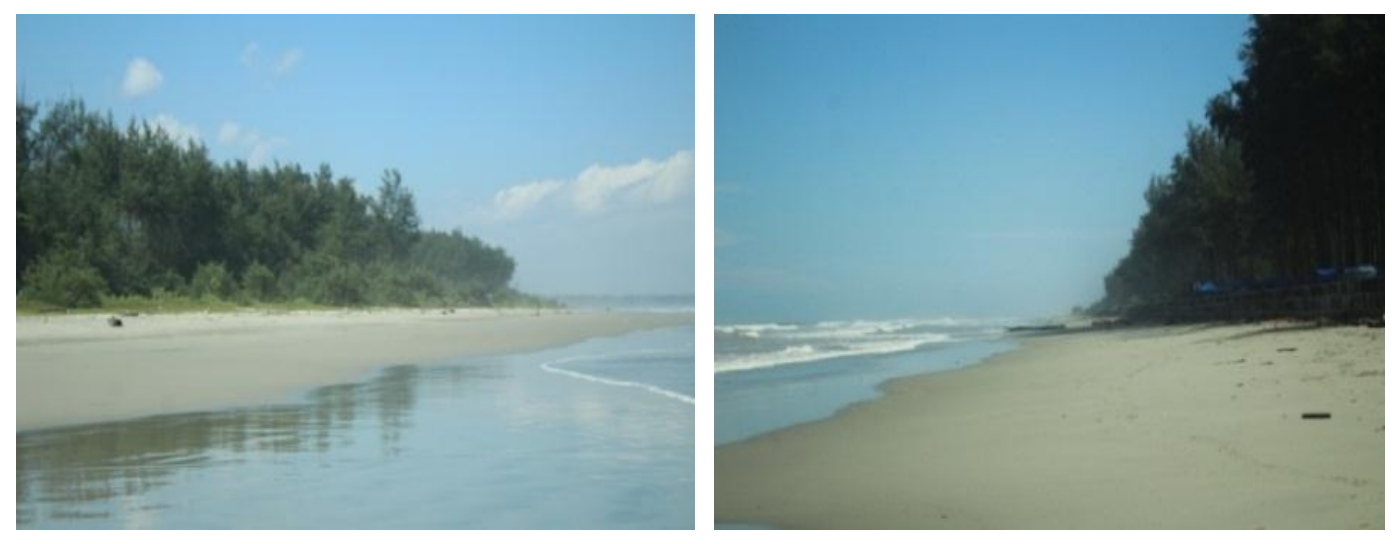

Gambar 9. Tipe pantai di Pantai Panjang 


\section{Material Dasar Perairan}

Material dasar perairan atau substrat merupakan penentu kecerahan suatu perairan pengamatan terhadap material dasar perairan dilakukan langsung di lapangan secara visual. Berdasarkan hasil di lapangan maka material dasar perairan di Pantai Panjang adalah pasir pada Stasiun 1, Stasiun 2, Stasiun 3 dan Stasiun 4. Material dasar perairan pasir berkarang pada Stasiun 5 yang dapat dilihat pada Gambar 10. Material dasar perairan berpasir menurut Yulianda (2007) sangat sesuai untuk kegiatan ekowisata pantai. Demikian juga menurut Margomgom dkk. (2013) bahwa material dasar perairan berupa pasir sangat sesuai untuk aktivitas ekowisata pantai seperti mandi dan berenang.
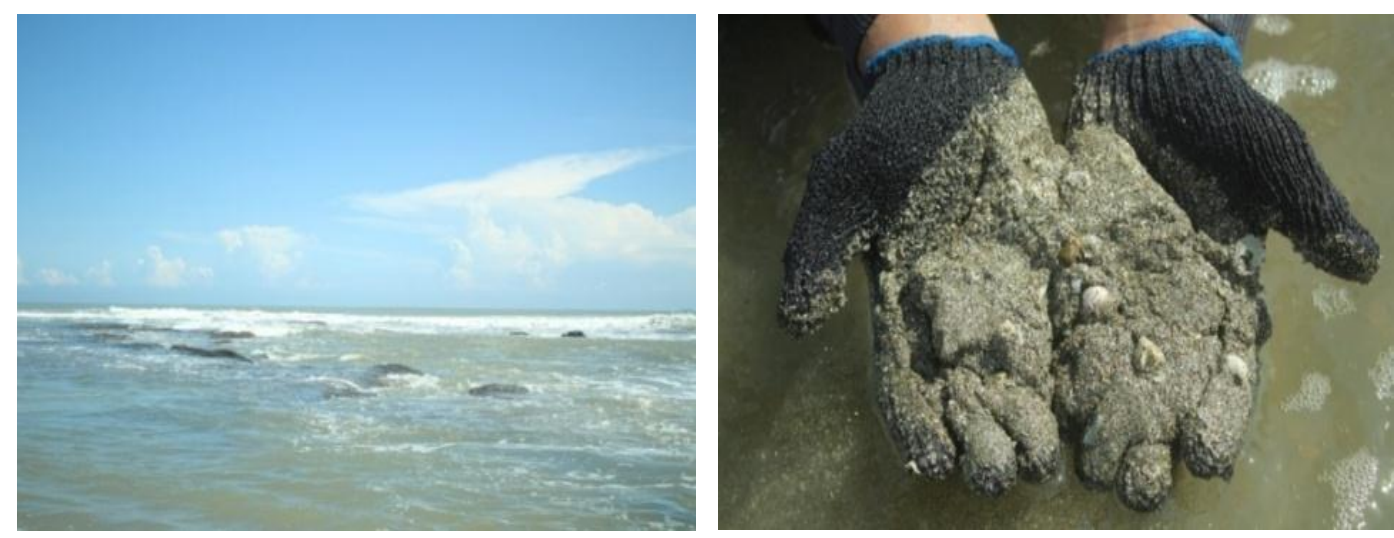

Gambar 10. Material dasar perairan Pantai Panjang

\section{Biota Berbahaya}

Pengamatan yang dilakukan selama pengambilan data lapangan secara visual termasuk ketika saat melakukan wawancara menggali informasi secara mendalam kepada nelayan, pengunjung dan masyarakat sekitar menunjukkan bahwa tidak ditemukan biota berbahaya di kawasan perairan Pantai Panjang, maka dapat mendukung aktifitas kegiatan ekowisata pantai.

Kegiatan ekowisata pantai tidak lepas dari ada tidaknya biota berbahaya pada kawasan pantai karena berhubungan dengan keamanan dan kenyamanan wisatawan tanpa ada rasa takut dan khawatir terhadap pantai yang akan dijadikan tempat berbagai aktivitas. Biota berbahaya bagi wisatawan di kawasan ekowisata pantai berupa karang api, gastropoda, bulu babi, landak laut, ubur-ubur dan ular laut. Menurut Pratesthi dkk., (2016), tidak adanya biota berbahaya pada perairan pantai akan membuat aman digunakan untuk kegiatan ekowisata pantai, berenang, dan snorkeling oleh wisatawan. 


\section{Penutupan Lahan Pantai}

Kawasan Pantai Panjang dapat dilihat pada Gambar 11 bahwa penutupan lahannya berupa pohon cemara, dan belukar rendah. Selain itu juga ditemukan pemukiman, hotel dan saung milik warga yang berjualan.

Penutupan lahan pantai adalah pemanfaatan yang dikelola terhadap kawasan disekitar pantai. Penutupan lahan pantai menurut Yulianda (2007), cukup sesuai untuk aktivitas ekowisata pantai. Dalam hubungan dengan pengembangan ekowisata pantai maka diperlukan pengelolaan pada kawasan hutan pantai.

Pengelolaan penutupan lahan pantai bertujuan untuk meningkatkan daya tarik ekowisata di kawasan pantai. Pengelolaan yang baik akan menghasilkan kelestarian kawasan sehingga perlu diperhatikan untuk tetap menjaga agar penutupan lahan di Pantai Panjang dikelola dengan baik.
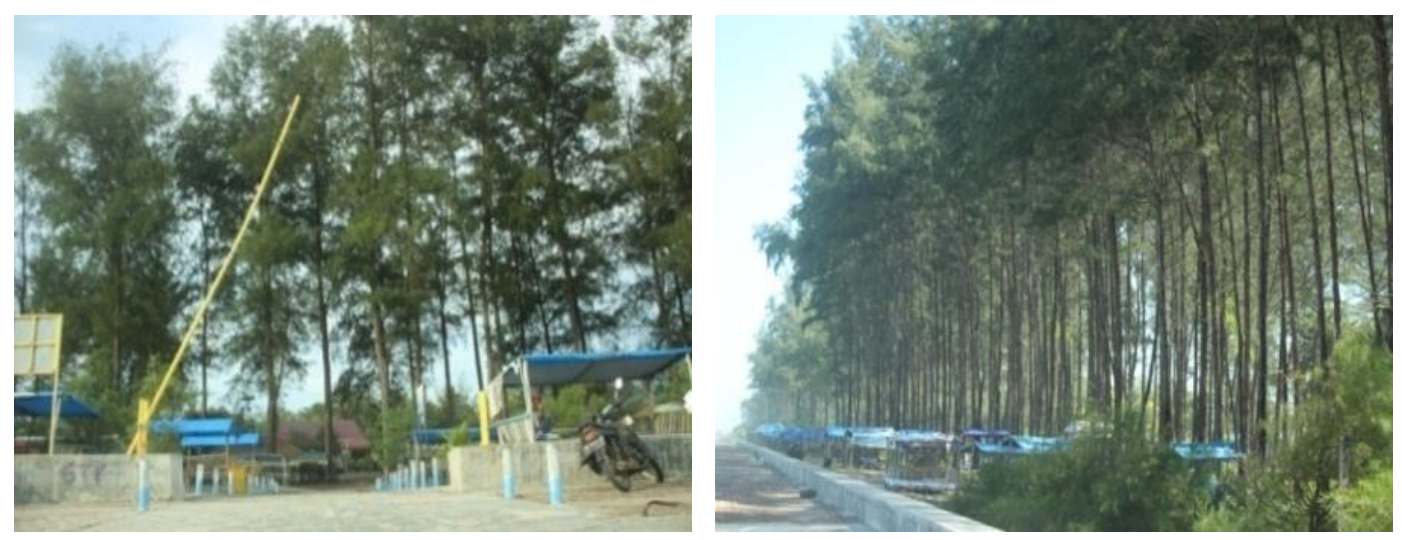

Gambar 11. Penutupan lahan pantai kawasan Pantai Panjang

\section{Jarak Ketersediaan Air Tawar}

Berdasarkan hasil penelitian di lapangan jarak antara ketersedian air tawar (Gambar 12) terdekat yaitu pada Stasiun 4 (25 m) dan ketersedian air tawar terjauh pada Stasiun $5(200 \mathrm{~m})$. Sebagaimana menurut Yulianda (2007) pada matriks kesesuaian lahan kategori ekowisata pantai bahwa suatu ekowisata pantai dapat dikatakan sangat sesuai jika memiliki jarak ketersediaan air tawar antara lokasi ekowisata pantai $<0,5 \mathrm{~km}$.

Ketersediaan air bersih berupa air tawar sangat dibutuhkan banyak oleh makhluk hidup, termasuk dalam menunjang fasilitas pengelolaan maupun pelayanan ekowisata. Hal ini juga merupakan menjadi kriteria peniliaian terhadap kelayakan prioritas pengembangan ekowisata pantai (Handayawati, 2010).

Menurut Armos (2013) air merupakan elemen penting di kawasan ekowisata untuk kebersihan seusai melakukan kegiatan di pantai. Oleh 
sebab itu, semakin dekat jarak antara garis pantai dan ketersediaan air tawar maka semakin baik kawasan itu dijadikan tempat ekowisata pantai.
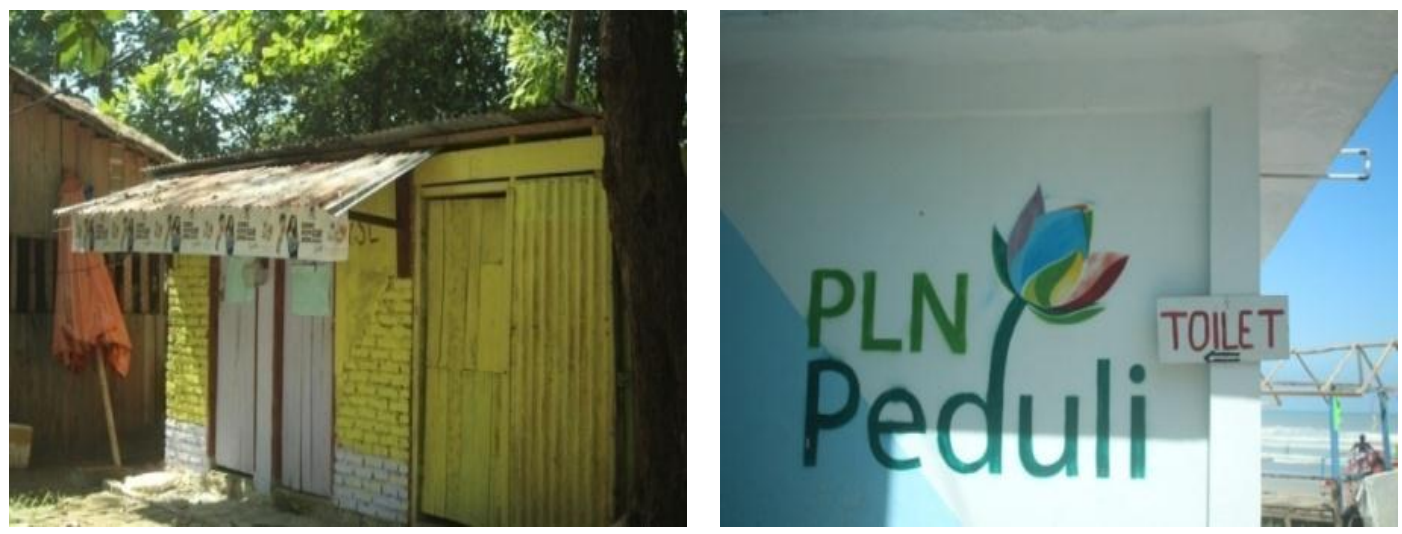

Gambar 12. Ketersediaan air tawar di Pantai Panjang

\section{KESIMPULAN}

Sebaran parameter oseanografi dan lingkungan dalam kondisi mendukung untuk kegiatan ekowisata pantai kategori rekreasi dan ekowisata pantai kategori olahraga dan berjemur. Pantai Panjang merupakan pantai pasir putih dengan garis pantai halus yang membentang sepanjang $7 \mathrm{~km}$ yang terletak di Kecamatan Ratu Agung, Kecamatan Teluk Segara, dan Kecamatan Ratu Samban. Pantai Panjang terletak sejajar dengan Pantai Tapak Paderi dan Pantai Jakat. Batas wilayah Pantai Panjang yaitu, Utara dengan daerah Kelurahan Penurunan, Selatan dengan Samudera Hindia, Barat dengan Kelurahan Sumur Meleleh, Pasar Pantai Malabro, dan Timur dengan daerah Lempuing Nusa Indah.

\section{DAFTAR PUSTAKA}

Armos, N. H. 2013. Studi kesesuaian Lahan Pantai Ekowisata Boe Desa Mappakalompo Kecamatan Galesong Ditinjau Berdasarkan Biogeofisik. Skripsi. Fakultas Ilmu Kelautan dan Perikanan. Universitas Hasanuddin, Makassar.

Bengen, D. G. 2002. Sinopsis Ekosistem Sumberdaya Alam Pesisir dan Laut serta Prinsip Pengelolaannya, Bogor. Pusat Kajian Sumberdaya Pesisir dan Lautan, Institut Pertanian Bogor, Bogor.

Bjork, P. 2000. Ecotourism from a conceptual perspective, an extended definition of a unique tourism form. International Journal of Tourism Research 2:189-202. 
Budiyono, D., dan Soelistyari, H.T. 2016. Evaluasi Kualitas Visual Lanskap Ekowisata Pantai Balembang di Desa Srigonco Kabupaten Malang. Jurnal Lanskap Indonesia 8 (2) : 80-90.

Effendi, H. 2003. Telaah Kualitas Air. Kanisius, Yogyakarta.

Fadrika, T. M., Rahmawaty, dan Harahap, Z. A. 2015. Kajian Potensi Untuk Ekowisata Di Pantai Lestari Indah Kabupaten Serdang Bedagai Sumatera Utara. Jurnal Aquacoastmarine 7 (2): 1-13.

Handayawati, H. 2010. Potensi Wisata Alam Pantai-Bahari. PM PSLP PPSUB.

Hazeri, G. 2014. Studi Kesesuaian Pantai Laguna Desa Merpas Kecamatan Nasal Kabupaten Kaur Sebagai Daerah Pengembangan Pariwisata dan Konservasi. Skripsi.Fakulatas Pertanian. Universitas Bengkulu, Bengkulu. (tidak dipublikasikan).

Isnaini, A. 2011. Penilaian Kualitas Air dan Kajian Potensi Situ Salam Sebagai Ekowisata Air di Universitas Indonesia Depok. Skripsi. Pascasarjana FMIPA. Universitas Indonesia, Depok.

Lelloltery, H., Pujiatmoko, S., Fandelli, C., dan Baiquni, M. 2016. Pengembangan Ekowisata Berbasis Kesesuaian dan Daya Dukung Kawasan Pantai (Studi Kasus Pulau Marsegu Kabupaten Seram Bagian Barat). Jurnal Budidaya Pertanian 12 (1) : 25-33.

Margomgom, J. T., Sutrisno, A., dan Hartuti, P. 2013. Kajian Kualitas Lingkungan dan Kesesuaian Wisata Pantai Tanjung Pesona Kabupaten Bangka. Prosiding Seminar Nasional Pengelolaan Sumberdaya Alam dan Lingkungan. 356-362.

Menteri Lingkungan Hidup. 2004. Keputusan Menteri Lingkungan Hidup Nomor 51 Tahun 2004 tentang Baku Mutu Air Laut. Kemnaker dan BPS, Jakarta.

Nugraha, H. P., Indarjo, A., dan Helmi, M. 2013. Studi Kesesuaian dan Daya Dukung Kawasan untuk Rekreasi Pantai di Pantai Panjang Kota Bengkulu. Journal of Marine Research 2 (2) : 130-139.

Nybakken, J. W. 1992. Biologi Laut. Suatu Pendekatan Ekologis. Gramedia, Jakarta.

Pratesthi, P. D. A, Frida P., dan Siti R. 2016. Studi Kesesuaian Wisata Pantai Nglambor Sebagai Objek Rekreasi Pantai Di Kabupaten Gunung Kidul. Management of Aquatic Resources 5 (4) : 433-442. 
Senoaji, G., dan M. F. Hidayat. 2019. Peranan Ekosistem Mangrove di Pesisir Kota Bengkulu dalamMitigasi Pemanasan Global Melalui Penyimpanan Karbon. J. Manusia dan Lingkungan 23 (3) : 327-333.

Sudarto, Y. 1993. Budidaya Waluh. Kanisius, Yogyakarta.

Susana, T. 2009. Tingkat Keasaman $(\mathrm{pH})$ dan Oksigen Terlarut Sebagai Indikator Kualitas Perairan Sekitar Muara Sungai Cisadane. Jurnal Teknologi Lingkungan. LIPI, Jakarta.

Wabang, I. L., Yulianda, F., dan Adisusanto, H. 2017.Kajian karakteristik tipologi pantai untuk pengembangan ekowisata rekreasi pantai di Suka Alam Perairan Selat Pantar Kabupaten Alor. Jurnal Albacore 1 (2) :199-209.

Yulianda F. 2007. Ekowisata Bahari sebagai Alternatif Pemanfaatan SumberdayaPesisir Berbasis Konservasi.Makalah Seminar Sains pada Departemen Manajemen Sumberdaya Perairan. Fakultas Perikanan dan IImu Kelautan IPB, Bogor.

Yulianda, F. A. Fahrudin, A. A. Hutabarat, S. Harteti, Kusharjani dan Kang, S. H. 2010. Pengelolaan Pesisir dan Laut Secara Terpadu. Pusdiklat Kehutanan Departemen Kehutanan RI, Jawa Barat.

Yusthisar, M., I. Pratikto, dan Koesoemadji. 2012. Tinjauan Parameter Fisik Pantai Mangkang Kulon Untuk Kesesuaian Pariwisata Pantai di Kota Semarang. Journal of Marine Research 1 (2) : 8-16. 